\title{
Gullies mitigation and control measures: A case study of the Seirós gullies (North of Portugal)
}

\author{
Bruno Martins $^{\mathrm{a}}$, Ana C. Meira Castro ${ }^{\mathrm{b}, \mathrm{c}, *}$, Carmen Ferreira ${ }^{\mathrm{d}}$, Luciano Lourenço ${ }^{\mathrm{a}}$, Adélia Nunes ${ }^{\mathrm{a}}$

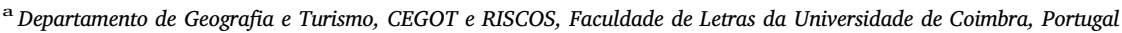 \\ ${ }^{\mathrm{b}}$ ISEP - School of Engineering, Polytechnic of Porto, Rua Dr. Antonio Bernardino de Almeida, 431, 4200-072, Porto, Portugal \\ ${ }^{c}$ CERENA_Polo FEUP - Centre for Natural Resources and the Environment, Faculty of Engineering of University of Porto, Rua Dr. Roberto Frias, Porto, 4200-465, Portugal \\ d Departamento de Geografia, CEGOT e RISCOS, Faculdade de Letras da Universidade do Porto, Portugal
}

\section{A R T I C L E I N F O}

\section{Keywords:}

Gully erosion

Soil degradation

Seirós (North of Portugal)

Strategy to prevent gullies

\begin{abstract}
A B S T R A C T
It is known that the erosion process triggered by gullies contributes to significant soil loss and land degradation, and this can limit the options for the occupation and development of a territory in terms of the suitability and quality of the farmland area. The variety of physical factors associated with gully formation hinders straightforward interpretations and requires well-grounded analysis based on local observation.

This work presents an example of gullies formed in a colluvial hill-slope agricultural area in Seirós, North of Portugal. The gullies were formed by intense rainfall events in 2015 that led to a channel overflowing. The channel in question was $49 \mathrm{~m}$ long, $0.50 \mathrm{~m}$ wide and $0.50 \mathrm{~m}$ deep and had been built by the landowner to protect his farmland from hillslope drainage. The adequacy of the strategy implemented to prevent gully formation with a view to the rehabilitation of the area is validated.
\end{abstract}

\section{Introduction}

Soil erosion caused by surface-water hydrodynamics is a serious geo-environmental problem that causes land degradation in semihumid to semi-arid Mediterranean countries (e.g. Martinez-Casasnovas, 2003; Vandekerckhove et al., 2003; Nunes et al., 2008, 2009; Tsimi et al., 2012; Frankl et al., 2012). It is also a major concern in these countries because it contributes to significant soil loss (Taddese, 2001; Tebebu et al., 2016).

Gullies are very often found in steeply mountain regions. Their formation is related not only to the climatic characteristics in the areas where they are formed, typically associated with long and intense rainfalls, but also to the topography of the site and anthropogenic action. In fact, slope gradient, length and shape, as well as the physical, chemical and mineralogical properties of the soil and its substrata clearly interfere through the availability (or absence) of cohesive materials. Once disintegrated, these form gullies that transport sediments that can be found in weathering profiles and/or in slope deposits (Poesen et al., 2003; Valentin et al., 2005). Road building, deforestation, ploughing, livestock grazing and the removal of remnants of vegetation are the most cited anthropogenic factors that are involved in gully erosion (Poesen et al., 2003). They contribute to the concentration of surface runoff and to the transfer of concentrated runoff to other catchments. In addition, they also help to eventually increase catchment size, which enhances gully development after roads have been built, especially when non-cohesive material is present (Nyssen et al., 2002; Douglas and Pietroniro, 2003; Ezezika and Adetona, 2011). Forest wildfires also encourage gully formation; after a wildfire event, the loss of the topsoil vegetation cover, which becomes more exposed to rainfall and wind events, and this enhances soil loss and the possibility of soil erosion (Meira-Castro et al., 2011, 2012, 2015).

Resulting from geomorphological processes, these forms of erosion increase sediment loss into nearby waterways and streams and lead to a reduction in the amount of deep water percolation because the soil pores are filled as the sediment-laden water infiltrates into the soil (Wasson et al., 2002; Krause et al., 2003; Vente et al., 2007; Vandekerckhovea et al., 2005; Bergonse and Reis, 2017). The silting up of reservoirs is another consequence of this process (Mekonnen et al., 2015). Several case studies have confirmed that the production of sediment due to gully erosion is not negligible (Poesen et al., 1998; Kheir et al., 2007) and suggest that the significance of this accelerated form of soil erosion warrants special attention. This is mainly because the soil loss and land degradation caused by gullies can limit the options for the occupation of the territory and its development in terms of the availability, suitability and quality of the productive area for agriculture, grazing and wood production (Hallet et al., 1996; Poesen, 2011).

\footnotetext{
* Corresponding author. ISEP - School of Engineering, Polytechnic of Porto, Rua Dr. Antonio Bernardino de Almeida, 431, 4200-072, Porto, Portugal.

E-mail address: amc@isep.ipp.pt (A.C. Meira Castro).
} 
The threats and hazards associated with gully erosion have aroused scientific interest in sediment delivery rates and volumetric expansion rates in an effort to improve the effectiveness and efficiency of strategies to control and mitigate the formation of gullies (Sidorchuk and Golosov, 2003; Sidorchuk, 2005; Hui et al., 2010; Ehiorobo and Ogirigbo, 2013).

In this work we present an example of gullies formed in a colluvial hillslope farmland area in Seirós, northern Portugal, caused by extreme rainfall in 2015. The gullies were created by the overflow from a channel of $49 \mathrm{~m}$ long, $0.70 \mathrm{~m}$ wide and $0.75 \mathrm{~m}$ deep built up by the landowner to protect his farmland from hillslope drainage. This episode had an enormous impact on farming the land, which was forced to stop for a year while the gullies were neutralized by machinery. At the same time, a partially destroyed protection channel was rebuilt as an on-site erosion control measure. This work characterizes the Seirós gullies and examines the factors determining the gullies' formation. In addition, the adequacy of the existing strategy to prevent gullies from forming, as implemented by the landowner in an effort to rehabilitate the area is analysed and discussed.

\section{Material and methods}

\subsection{The study area}

The Seirós gullies are located between the Beça and Tâmega rivers in the North region of Portugal (Fig. 1). The study area includes autochthonous terranes of the Central Iberian Zone (ITCZ) and parautochthonous terranes of the Galicia-Trás-os-Montes Zone (ZGTM), particularly its SE branch (Ribeiro, 2011a). This area lies within a pelite-greywacke Silurian formation composed of grey shales with interbedded black shale, and ampelites, lydites, with alternating psammitic pelites, greywackes and volcanic tuff.

Gullies formed in a shallow leptosol and colluvium. The colluvium is characterized by an orange coloured soil with the presence of round clasts that rarely exceed $30 \mathrm{~cm}$ in diameter. Soil analysis shows an average of $20 \%$ of silt and clay and a texture dominated by $0.125 \mathrm{~mm}$ and $0.063 \mathrm{~mm}$ fractions. Median values range between 0.2 and $0.34 \mathrm{~mm}$ with an average range between 0.36 and $1.15 \mathrm{~mm}$. The average calibration value is 2.47 and range between 3.16 and 1.38 . The average asymmetry value is 2.08 and kurtosis is 1.87 .

As in most of the country, the climate of the area under study has Mediterranean characteristics (Cs). Thermopluviometric analysis in the meteorological stations in the Portuguese Institute for Sea and Atmosphere (IPMA) network indicates only two dry months (July and August) (rainfall in mm equal to or lower than twice the mean monthly temperature in ${ }^{\circ} \mathrm{C}$ ). Annual precipitation ranges between $1200 \mathrm{~mm}$ and $1400 \mathrm{~mm}$ and is sometimes torrential in nature. Although hourly data are sparse, precipitation above $50 \mathrm{~mm}$ can give some indication of the occurrence of high intensity storms. The precipitation concentration index (PCI) for the wettest months (January and December) can be estimated using eq. (1):

PCI $=\frac{\sum_{i=1}^{12} P_{i}^{2}}{\left(\sum_{i=1}^{12} P_{i}\right)} \times 100$

where $P_{i}$ is the month of highest precipitation $(\mathrm{mm})$ and $P$ is the average annual rainfall $(\mathrm{mm})$. Their values are respectively about 10 and $20 \%$. In spite of these moderate values, anthropogenic factors play a significant part in gully formation and development, and in the associated soil loss rates. Deforestation, forest fires, overgrazing, vegetation removal, and road building, are the most important ones. In most cases they reduce infiltration and promote runoff water concentration (Nunes et al., 2016; Lourenço et al., 2012).

\subsection{Data collection and computing}

The Seirós gullies were monitored from December 2015, when they were formed, to July 2017. Farming activity stopped between December 2015 and December 2016 due to the damage caused by the gullies. After this period, the landowner neutralized the gullies by
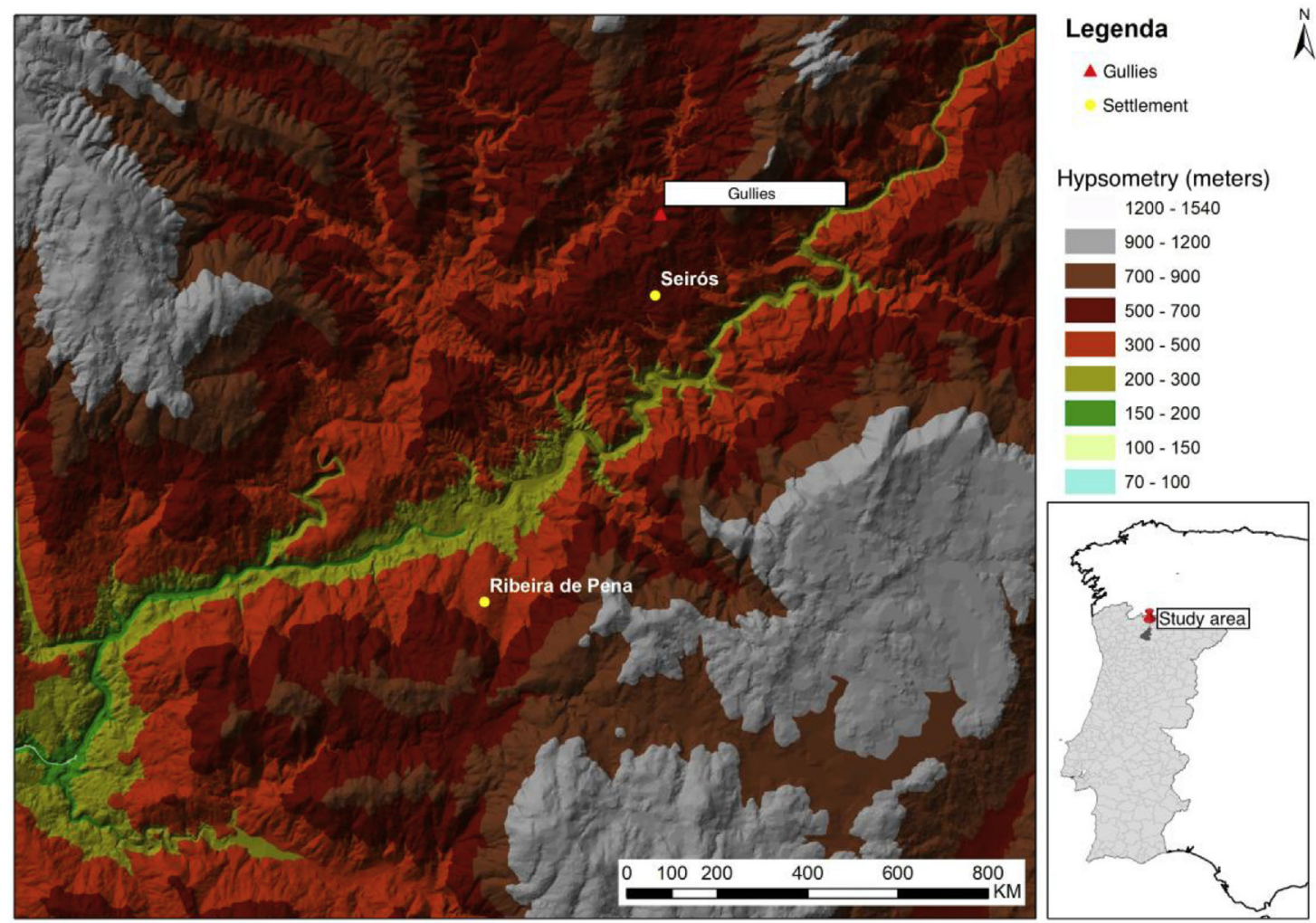

Fig. 1. Seirós' gullies localization. 
means of machinery in order to resume farming and preserve the nearby water reservoir. At the same time, the channel that had been constructed to try and prevent gully erosion was repaired. The channel (built in early 2015) was $49 \mathrm{~m}$ long, $0.70 \mathrm{~m}$ wide and $0.80 \mathrm{~m}$ deep.

The gullies' morphology was characterized using a graduated iron bar to obtain slope measurements, and a compass was used to indicate the direction of their alignment. The distance between measuring points was about $1 \mathrm{~m}$ except when there were significant changes in the gully profile, that is, in its width and/or its depth.

Rainfall data was obtained directly from IPMA and from the National Information System of Hydric Resources (SNIRH).

The flow capacity of the drainage channel and the flow generated by the precipitation episode that led to the formation of the gullies were estimated. The watershed runoff rate, $\mathrm{Q}$, in $\mathrm{m} 3 / \mathrm{s}$ generated by a precipitation episode was then calculated according to the rational method for precipitation/runoff models (Eq. (2)). Because of its simplicity and accuracy this method is considered suitable for hydrological problems in small basins (Lencastre, 1983). Thus,

$Q=C . I . A$

where $C$ is a dimensionless runoff-to-rainfall coefficient, I (m3/s/m2) represents the rainfall intensity and $\mathrm{A}\left(\mathrm{m}^{2}\right)$ is the contributing watershed area. The drainage area was determined using ArcGIS software and was delimited by analysing the level curves and the orientation of the flow. A 4,9-hectare high slope watershed area was considered. The capacity of the open drainage channel to transport the generated runoff (considering uniform flow and permanent regime) was computed based on both the continuity equation (Eq. (3)) and the Manning-Strickler velocity equation (Eq. (4)), as follows:

$Q=S_{m} . V$

$V=K \cdot R^{\frac{2}{3}} \cdot J^{\frac{1}{2}}$

where $\mathrm{Q}(\mathrm{m} 3 / \mathrm{s})$ represents the generated runoff flow into the channel, $\mathrm{Sm}\left(\mathrm{m}^{2}\right)$ is the channel's wetted section, $\mathrm{V}(\mathrm{m} / \mathrm{s})$ is the flow velocity, $\mathrm{K}$ is Manning's roughness coefficient, $\mathrm{R}(\mathrm{m})$ is the hydraulic radius and $\mathrm{J}$ $(\mathrm{m} / \mathrm{m})$ is the channel slope.

\section{Results and discussion}

\subsection{Gullies morphology}

Gully formation resulted from overflows from the channel built to control runoff water from a 4 ha drainage area (Fig. 2 left). In December 2015, a network of 8 gullies was formed (Fig. 2 centre and right) over a short period due to an extreme rainfall event between 8 p.m. on 14 December and 2 a.m. on 15 December (Fig. 3). Precipitation could also have been involved in soil saturation, which in turn led to the increased runoff. Based on the information provided by nearby meteorological stations at Boticas and Celorico de Basto, three periods of intense precipitation occurred before the formation of ravines. One was at the beginning of November, another shorter and less intense period occurred between 21 and 23 November, and then came the heaviest with the highest amount of accumulated precipitation, which led to the formation of gullies, between 7 and 9 December. Subsequently, from 13 December, another period of intense precipitation began, after which the gullies under study were formed (Fig. 4).

The gullies' characteristics are described by the variables listed in Table 1 . They are between $6 \mathrm{~m}$ and $22 \mathrm{~m}$ long, between $0.3 \mathrm{~m}$ and $2.1 \mathrm{~m}$ deep, and between 0.4 and $1.7 \mathrm{~m}$ wide.

The width-to-depth ratio (WDR) ranged from 0.8 to 3.2 and the total soil loss is expected to reach $284 \mathrm{~m}^{3}$.

The increase in gully dimensions was affected by a colluvium layer, as revealed by the strong and positive correlation between gully depth and the thickness of the colluvium $(r=0,64)$.

From the morphological point of view, it is possible to identify two types of gullies.

The first group constituted by gullies with the longest and deepest values (G1, G2 and G5), and the second group, constituted by gullies with the shorter and wider values (G3, G4, G6, G7 and G8).

The correlation between gully depth and length is $r=0,63$. There is also a positive and moderate correlation between gully length and the volumetric soil loss as well as between gully length and soil loss by weight $(r=0.60$ and $r=0.58$ respectively). The correlation between WDR and volumetric soil loss is negative and moderate $(r=-0.50)$. The correlation between WDR and soil loss by weight is also negative, but a little bit higher $(r=-0.60)$.

\subsection{Open channel flow characterization}

According to Eq. (2), and considering a runoff-to-rainfall coefficient for colluvium soils of 0.82 (dimensionless), a rainfall scenario of $15 \mathrm{~mm}$ per hour (considered to be an extreme value) and a drainage area of $4.9 \mathrm{ha}$, the watershed runoff $\mathrm{Q}$ is $0.17 \mathrm{~m}^{3} / \mathrm{s}$. Therefore, and according to the precipitation/runoff model whose results are presented in Table 2 , the solution currently used to prevent the formation of gullies may not be adequate.

There is no explicit solution for calculating the water depth in an open channel and therefore the calculation involves trial-and-error solution procedure. Therefore, simulations were conducted that considered variations in water depth in the channel, and assumed a constant channel base wide of $0.50 \mathrm{~m}$, a flow of $0.17 \mathrm{~m}^{3} / \mathrm{s}$, a roughness coefficient of 40 , a channel slope of $0.1 \%$ and a maximum precipitation value of $15 \mathrm{~mm} / \mathrm{h}$. In these conditions, the value for $A_{w} R^{2 / 3}=Q /(K J$ $\left.{ }^{(1 / 2)}\right)$ obtained from equations (3) and (4), corresponds to $0.132\left(\mathrm{~m}^{8 / 3}\right)$ and is used in Table 2 as a reference value.

According to the results obtained, it is possible to conclude that the channel cross section of $0.50 \times 0.60 \mathrm{~m}^{2}$ was insufficient to drain the exceptional flow generated by a rainfall of $15 \mathrm{~mm} / \mathrm{h}$. Similar conditions were reported in 2015 in the Ene-Chilala catchment by Addisie and coresearchers (Addisie et al., 2016). The six scenarios presented in Table 2 confirm that by altering the channel's cross-section geometry in

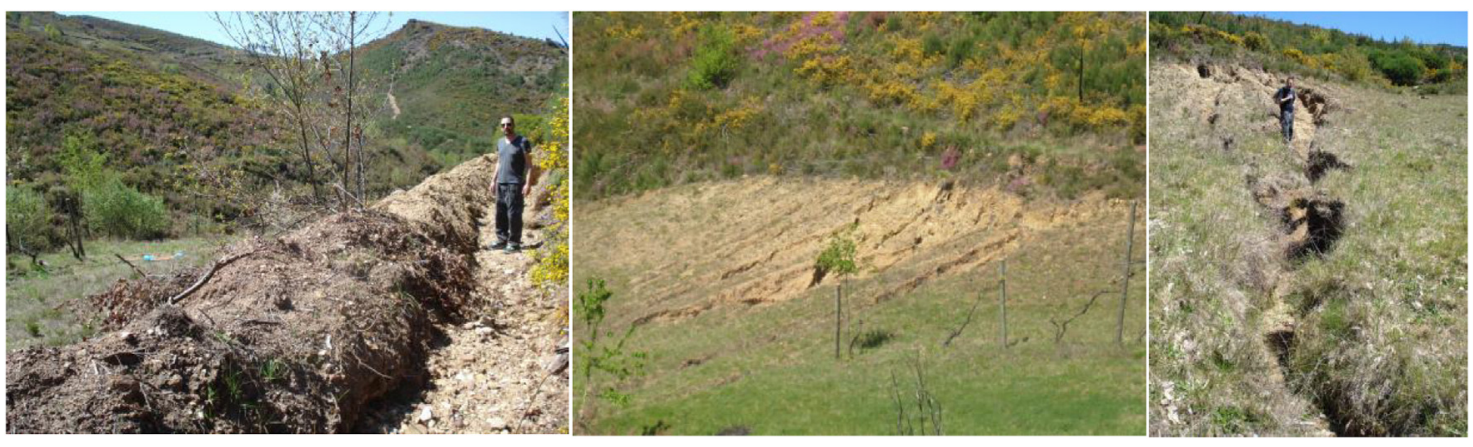

Fig. 2. Seirós runoff water channel (left); view of gullies in July 2016 (centre); a gully detail (right). 


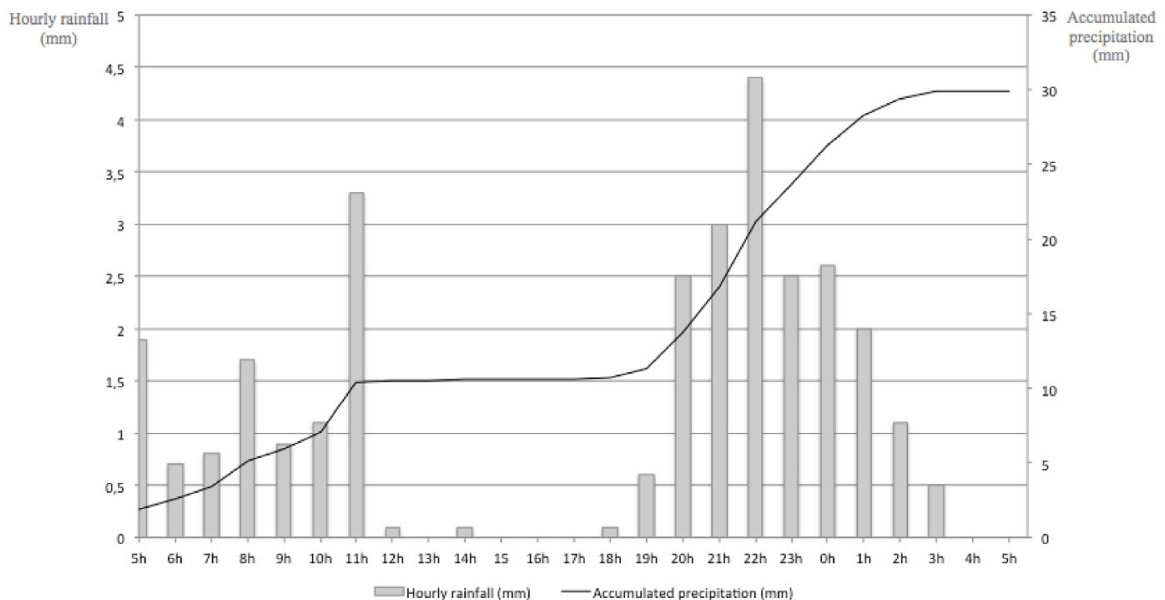

Fig. 3. Cumulative precipitation and hourly precipitation values, between 5 a.m. on 14 and 5 a.m. on 15 December (data source: SNIRH).

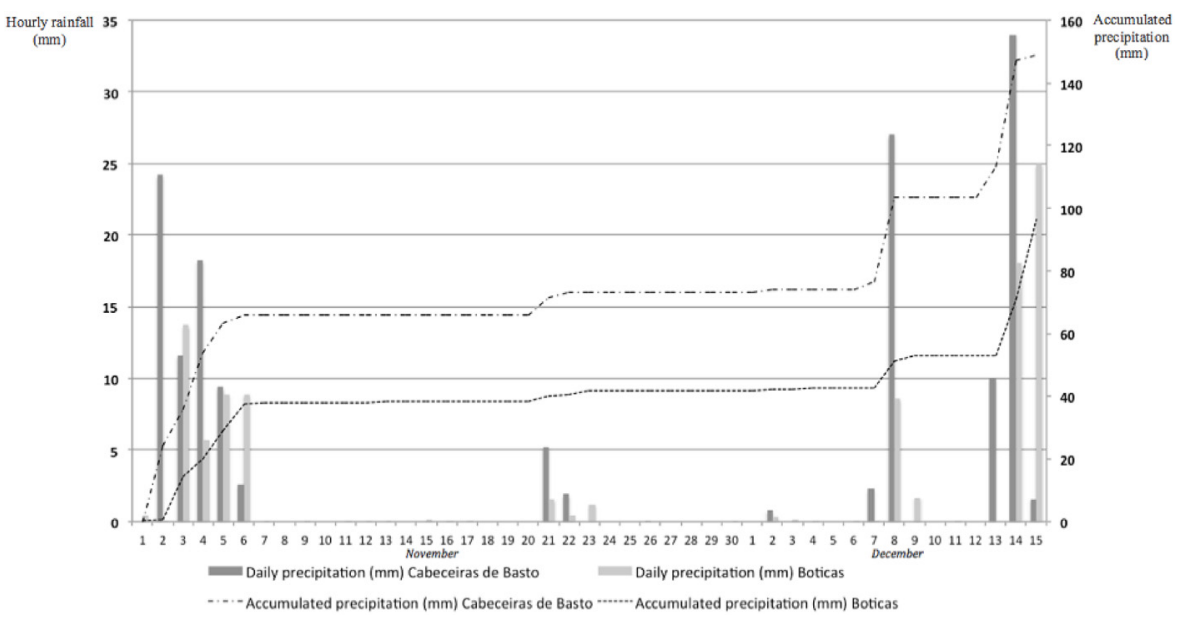

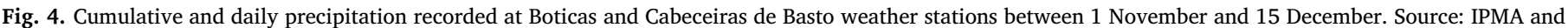
SNIRH.

Table 1

Most important morphological characteristics of gullies and measures of soil loss.

\begin{tabular}{|c|c|c|c|c|c|c|c|c|c|c|c|}
\hline Gully ID & $\begin{array}{l}\text { Total } \\
\text { length (m) }\end{array}$ & $\begin{array}{l}\text { Mean } \\
\text { width (m) }\end{array}$ & $\begin{array}{l}\text { Mean } \\
\text { depth (m) }\end{array}$ & WDR & $\begin{array}{l}\text { Surface slope } \\
\text { above gully head } \\
\left(\mathrm{m} \mathrm{m}^{-1}\right)\end{array}$ & $\begin{array}{l}\text { Friction } \\
\text { angle }\left({ }^{\circ}\right)\end{array}$ & $\begin{array}{l}\text { Channel slope } \\
\left(\mathrm{m} \mathrm{m}^{-1}\right)\end{array}$ & $\begin{array}{l}\text { Plan } \\
\text { area } \\
\left(\mathrm{m}^{2}\right)\end{array}$ & $\begin{array}{l}\text { Mean colluvium } \\
\text { depth }(\mathrm{m})\end{array}$ & $\begin{array}{l}\text { Volumetric soil } \\
\text { loss }\left(\mathrm{m}^{3}\right)\end{array}$ & $\begin{array}{l}\text { Soil loss by } \\
\text { weight (ton) }\end{array}$ \\
\hline G 1 & 22 & 1.4 & 1.2 & 1.2 & 0.09 & 0.23 & 39.8 & 1.3 & 54.1 & 80.2 & 22 \\
\hline G 2 & 19 & 1.7 & 2.1 & 0.8 & 0.03 & 0.08 & 42.4 & 2.5 & 108.4 & 165.9 & 19 \\
\hline G 3 & 12 & 0.4 & 0.3 & 1.6 & 0.08 & 0.18 & 3.8 & 0.6 & 1.5 & 1.2 & 12 \\
\hline G 4 & 15 & 0.6 & 0.4 & 1.6 & 0.04 & 0.06 & 7.2 & 0.4 & 3.8 & 2.9 & 13 \\
\hline G 5 & 18 & 1.1 & 0.9 & 1.2 & 0.07 & 0.07 & 16.7 & 0.9 & 15.2 & 17.9 & 18 \\
\hline G 6 & 13 & 0.8 & 0.3 & 3.2 & 0.03 & 0.07 & 4.8 & 0.9 & 1.4 & 1.3 & 14 \\
\hline G 7 & 13 & 0.5 & 0.4 & 1.1 & 0.04 & 0.08 & 4.2 & 0.3 & 1.1 & 0.8 & 12 \\
\hline G 8 & 6 & 0.6 & 0.5 & 1.3 & 0.08 & 0.21 & 22.2 & 0.4 & 14.6 & 13.7 & 11 \\
\hline
\end{tabular}

$\mathrm{WDR}=$ width depth ratio.

Data collected in July 2016.

Table 2

Changes in channel capacity, varying water height and considering constant a flow, roughness coefficient, channel wide and slope.

\begin{tabular}{|c|c|c|c|c|c|c|}
\hline Water depth in the channel $y$ & Wet section area $S_{w}=b . y$ & Wet perimeter $P_{w}=b+2 \mathrm{y}$ & Hydraulic radius $R=S_{w} / P_{w}$ & $\mathrm{~S}_{w} \cdot \mathrm{R}^{(2 / 3)}$ & \multicolumn{2}{|c|}{$S_{w} R^{(2 / 3)}=Q /\left(K \cdot J^{(1 / 2)}\right)$} \\
\hline \multicolumn{7}{|l|}{$b=0.50$} \\
\hline 0.90 & 0.45 & 2.30 & 0.20 & 0.15 & 0,13 & OK \\
\hline 0.80 & 0.40 & 2.10 & 0.19 & 0.13 & & OK \\
\hline 0.70 & 0.35 & 1.90 & 0.18 & 0.11 & & insufficient \\
\hline 0.60 & 0.30 & 1.70 & 0.18 & 0.09 & & insufficient \\
\hline 0.50 & 0.25 & 1.50 & 0.17 & 0.08 & & insufficient \\
\hline
\end{tabular}


increments of $10 \mathrm{~cm}$ depth it is possible to conclude that a minimum of $0.70 \mathrm{~m}$ is needed and $0.90 \mathrm{~m}$ will give a comfortable safety margin to prevent channel overflow. Increasing the depth of the channel will reduce the risk of gully formation.

\section{Conclusions}

Gully erosion in Seirós had caused farmland degradation by soil leaching and sedimentation. The gullies resulting from an accumulation of severe rainfall events that occurred between November and December 2016 led to a channel overflowing that was built to protect farmland from the hillslope drainage.

Gully depth is closely related to the presence of colluvium. Gully formation benefits from the presence of unconsolidated material and gullies develop vertically. The artificial channel helped to concentrate surface runoff, which enhanced gully development.

Based on the results obtained by the simulation, it becomes clear that for similar values of precipitation the channel as it now is will overflow again and gullies will be formed again, too. The simulation model presented aims to estimate the flow capacity of the drainage channel and also the flow generated by a precipitation episode that originated the gullies, obtained according to the rational method for a precipitation/runoff model.

As a mitigating measure, it is suggested that the channel the crosssection should be adapted by increasing its depth to $0.90 \mathrm{~m}$. Other alternatives for improving the retention capacity of the channel, such as changing its width and/or slope, could be considered. However, figure for the depth should be viewed with caution because significant variations in land use will certainly interfere with the soil capacity to absorb infiltrated precipitation. Therefore, mitigation measures to prevent and control gully formation should be considered, in particular by providing vegetation cover and avoiding or reducing tillage.

\section{Acknowledgements}

The authors gratefully acknowledge the support of the Centro de Recursos Naturais e Ambiente (CERENA) funded by FCT (Strategic project FCT-UID/ECI/04028/2013).

\section{References}

Addisie, M., Ayele, G., Gessess, A., Tilahun, A., Zegeye, A., Moges, M., Schmitter, P. Langendoen, J., Steenhuis, T., 2016. Gully head retreat in the sub-humid Ethiopian highlands: the Ene-Chilala catchment. Land Degrad. Dev. 28 (5), 1579-1588. https:// doi.org/10.1002/ldr.2688.

Bergonse, R.; Reis, E. (2011). Controlling factors of the size and location of large gully systems: a regression-based exploration using reconstructed pre-erosion topography, Volume 147, p.621-631 https://doi.org/10.1016/j.catena.2016.08.014.

Douglas, I., Pietroniro, A., 2003. Predicting road erosion rates in selectively logged tropical rain forests. In: de Boer, D., Froehlich, W., Mizuyama, T. (Eds.), Erosion Prediction in Ungauged Basins, Integrating Methods and Techniques. Proceedings of an International Symposium Sapporo, Japan, 8-9 July 2003. IAHS Press, Wallingford, UK, pp. 199-205.

Ehiorobo, J., Ogirigbo, O., 2013. Gully morphology and gully erosion control in Calabar, cross river state, Nigeria. Adv. Mater. Res. 824, 656-666. https://doi.org/10.4028/ www.scientific.net/AMR.824.656.

Ezezika, O., Adetona, O., 2011. Resolving the gully erosion problem in Southeastern Nigeria: innovation through public awareness and community-based approaches. J. Soil Sci. Environ. Manag. 2 (10), 286-291. http://www.academicjournals.org/ journal/JSSEM/article-abstract/8BBD5123409.

Frankl, A., Poesen, J., Deckers, J., Mitiku, H., Nyssen, J., 2012. Gully head retreat rates in the semiarid Highlands of North Ethiopia. Geomorphology 173-174, 185-195. https://doi.org/10.1016/j.geomorph.2012.06.011.

Hallet, B., Hunter, L., Bogen, J., 1996. Rates of erosion and sediment evacuation by glaciers: A review of field data and their implications. Global Planet. Change 12 (1-4), 213-235. https://doi.org/10.1016/0921-8181(95)00021-6.

Hui, L., Xiaoling, C., Lim, K., Xiaobin, C., Sagong, M., 2010. Assessment of soil erosion and sediment yield in Liao watershed, Jiangxi Province, China, Using USLE, GIS, and
RS. J. Earth Sci. 21 (6), 941-953. https://doi.org/10.1007/s/12583-010-0147-4.

Kheir, R., Wilson, J., Deng, Y., 2007. Use of terrain variables for mapping gully erosion susceptibility in Lebanon. Earth Surf. Process. Landforms 32, 1770-1782. https://doi. org/10.1002/esp.1501.

Krause, A., Franks, S., Kalma, J., Loughran, R., Rowan, J., 2003. Multi parameter fingerprinting of sediment deposition in a small gullied catchment in SE Australia Catena 53 (4), 327-348. https://doi.org/10.1016/S0341-8162(03)00085-7.

Lencastre, Armando, 1983. Hidráulica Geral. In: Autor (Ed.), 650 p.

Lourenço, Luciano, Nunes, Adélia, Bento-Gonçalves, António, Vieira, António, 2012. In: Godone, Danilo, Stanchi, Silvia (Eds.), Soil Erosion after Wildfires in Portugal: What happens when heavy Rainfall Events Occur? Soil Erosion. InTech - Open Access Company980-953-307-558-2,

Martinez-Casasnovas, 2003. A spatial information technology approach for the mapping and quantification of gully erosion. Catena 50, 293-308. Elsevier. https://doi.org/ 10.1016/S0341-8162(02)00134-0.

Meira-Castro, A., Carvalho, J., Ribeiro, S., 2011. Prescribed burning impact on forest soil properties - a fuzzy boolean nets approach. Environ. Res. 111 (2), 199-204. ISSN: 0013-9351. https://doi.org/10.1016/j.envres.2010.03.004.

Meira-Castro, A., Carvalho, J., Meixedo, J., 2012. A qualitative description of soil parameters variation due to a prescribed fire in Portuguese northwestern forests using Fuzzy Boolean Nets - the case study of Cabreira mountain. Geoderma 191, 89-96. https://doi.org/10.1016/j.geoderma.2012.02.008.

Meira-Castro, A., Shakesby, R., Espinha Marques, J., Doerr, S., Meixedo, J., Teixeira, J., Chamine, H., 2015. Effects of prescribed fire on surface soil in a Pinus pinaster plantation, northern Portugal. Environ. Earth Sci. 73, 3011-3018. https://doi.org/ 10.1007/s12665-014-3516-y.

Mekonnen, M., Keesstra, D., Baartman, J.E. Ritsema, J., Melesse, M., 2015. Evaluating sediment storage dams: structural off-site sediment trapping measures in northwest Ethiopia. Cuadernos de Investigación Geográfica 41, 7-22.

Nunes, A., Lourenço, L., Meira-Castro, A., 2016. Exploring spatial patterns and drivers of forest fires in Portugal (1980-2014). Sci. Total Environ. 573, 1190-1202. https://dx. doi.org/10.1016/j.scitotenv.2016.03.121.

Nunes, J.P., Seixas, J., Pacheco, N.R., 2008. Vulnerability of water resources, vegetation productivity and soil erosion to climate change in Mediterranean watersheds. Hydrol. Process. 22, 3115-3134. https://doi.org/10.1002/hyp.6897.

Nunes, J.P., Seixas, J., Keizer, J.J., Ferreira, A.J.D., 2009. Sensitivity of runoff and soil erosion to climate change in two Mediterranean watersheds. Part II: assessing impacts from changes in storm rainfall, soil moisture and vegetation cover. Hydrol. Process. 23, 1212-1220. https://doi.org/10.1002/hyp.7250.

Nyssen, J., Moeyersons, J., Poesen, J., Deckers, J., Mitiku, H., 2002. The environmental significance of the remobilisation of ancient mass movements in the Atbara-Tekeze headwaters, Northern Ethiopia. Geomorphology 49, 303-322. https://doi.org/10. 1016/S0169-555X(02)00192-7.

Poesen, Jean, 2011. Challenges in gully erosion research. Landf. Anal. 17, 5-9.

Poesen, J.W., Vandaele, K., Van Wesemael, B., 1998. Gully erosion: importance and model implications. In: In: Boardman, J., Favis- Mortlock, D. (Eds.), Modelling Soil Erosion by Water. NATO AS Series, vol. I. Springer-Verlag, Berlin, pp. 285-311 55.

Poesen, J., Nachtergaele, J., Verstraeten, G., Valentin, C., 2003. Catena 50, 91-133. https://doi.org/10.1016/S0341-8162(02)00143-1.

Ribeiro, António, 2011a. A Evolução Geodinâmica de Portugal; uma introdução. In: Geologia de Portugal.

Sidorchuk, A., 2005. Stochastic component in the gully erosion modeling. Catena 39, 299-317. https://doi.org/10.1016/j.catena.2005.06.007.

Sidorchuk, A., Golosov, V., 2003. Erosion and sedimentation on the Russian plain. In: The History of Erosion and Sedimentation during the Period of Intensive Agriculture, Hydrological Process, vol. 17. pp. 3347-3358. 6. https://doi.org/10.1002/hyp.1391.

Taddese, G., 2001. Land degradation: a challenge to Ethiopia. Environ. Manag. 27, 815-824. https://doi.org/10.1007/s002670010190.

Tebebu, T., Bayabil, H., Stoof, C., Giri, S., Gessess, A., Tilahun, S., Steenhuis, T., 2016 Characterization of Degraded Soils in the Humid Ethiopian Highlands. Land Degrad. Dev. https://doi.org/10.1002/ldr.2687.

Tsimi, C., Ganas, A., Dimoyiannis, D., 2012. Catchment-wide estimate of single storm interrill soil erosion using an aggregate instability index: a model based on geographic information systems. Nat. Hazards 62, 863. https://doi.org/10.1007/s11069012-0114-8.

Valentin, C., Poesen, J., Li, Yong, 2005. Gully erosion: impacts, factors and control. Catena 63, 132-153. https://doi.org/10.1016/j.catena.2005.06.001.

Vandekerckhovea, L., Oostwoud, D., Figueiredo, T., 2005. Topographical thresholds for ephemeral gully initiation in intensively cultivated areas of the Mediterranean. Catena 33 (3-4), 271-292. https://doi.org/10.1016/S0341-8162(98)00068-X.

Vandekerckhove, L., Poesen, J., Govers, G., 2003. Medium-term gully headcut retreat rates in Southeast Spain determined from aerial photographs and ground measurements. Catena 50, 329-352. https://doi.org/10.1016/S0341-8162(02)00132-7.

Vente, J., Poesen, J., Arabkhedri, M., Gert Verstraeten, G., 2007. The sediment delivery problem revisited. Prog. Phys. Geogr. 31 (2), 155-178. https://doi.org/10.1177/ 0309133307076485 .

Wasson, R., Caitcheon, G., Murray, A., Mcculloch, M., Quade, J., 2002. Sourcing sediment using multiple tracers in the catchment of Lake Argyle, northwestern Australia. Environ. Manag. 29 (5), 634-646. https://doi.org/10.1007/s00267-001-0049-4. 